\title{
Front Matter: Volume 7052
}

, "Front Matter: Volume 7052," Proc. SPIE 7052, Organic Photovoltaics IX, 705201 (7 October 2008); doi: 10.1117/12.813259

SPIE Event: Photonic Devices + Applications, 2008, San Diego, California, United SPIE. States 


\section{PROCEEDINGS OF SPIE}

\section{Organic Photovoltaics IX}

Zakya H. Kafafi

Paul A. Lane

Editors

12-14 August 2008

San Diego, California, USA

Volume 7052 
The papers included in this volume were part of the technical conference cited on the cover and title page. Papers were selected and subject to review by the editors and conference program committee. Some conference presentations may not be available for publication. The papers published in these proceedings reflect the work and thoughts of the authors and are published herein as submitted. The publisher is not responsible for the validity of the information or for any outcomes resulting from reliance thereon.

Please use the following format to cite material from this book:

Author(s), "Title of Paper," in Organic Photovoltaics IX, edited by Zakya H. Kafafi, Paul A. Lane, Proceedings of SPIE Vol. 7052 (SPIE, Bellingham, WA, 2008) Article CID Number.

ISSN 0277-786X

ISBN 9780819472724

Published by

SPIE

P.O. Box 10, Bellingham, Washington 98227-0010 USA

Telephone +1 3606763290 (Pacific Time) · Fax +1 3606471445

SPIE.org

Copyright (C 2008, Society of Photo-Optical Instrumentation Engineers

Copying of material in this book for internal or personal use, or for the internal or personal use of specific clients, beyond the fair use provisions granted by the U.S. Copyright Law is authorized by SPIE subject to payment of copying fees. The Transactional Reporting Service base fee for this volume is $\$ 18.00$ per article (or portion thereof), which should be paid directly to the Copyright Clearance Center (CCC), 222 Rosewood Drive, Danvers, MA 01923. Payment may also be made electronically through CCC Online at copyright.com. Other copying for republication, resale, advertising or promotion, or any form of systematic or multiple reproduction of any material in this book is prohibited except with permission in writing from the publisher. The CCC fee code is $0277-786 \mathrm{X} / 08 / \$ 18.00$.

Printed in the United States of America.

Publication of record for individual papers is online in the SPIE Digital Library.

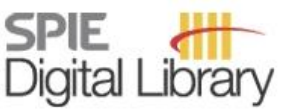

SPIEDigitallibrary.org

Paper Numbering: Proceedings of SPIE follow an e-First publication model, with papers published first online and then in print and on CD-ROM. Papers are published as they are submitted and meet publication criteria. A unique, consistent, permanent citation identifier (CID) number is assigned to each article at the time of the first publication. Utilization of CIDs allows articles to be fully citable as soon they are published online, and connects the same identifier to all online, print, and electronic versions of the publication. SPIE uses a six-digit CID article numbering system in which:

- The first four digits correspond to the SPIE volume number.

- The last two digits indicate publication order within the volume using a Base 36 numbering system employing both numerals and letters. These two-number sets start with 00, 01, 02, 03, 04, 05, $06,07,08,09,0 A, 0 B \ldots .0 Z$, followed by $10-1 Z, 20-2 Z$, etc.

The CID number appears on each page of the manuscript. The complete citation is used on the first page, and an abbreviated version on subsequent pages. Numbers in the index correspond to the last two digits of the six-digit CID number. 


\section{Contents}

vii Conference Committee

ix Commercialization of large-scale CPV: What lies ahead? (Plenary Paper) [7043-104]

D. Holland, Solar Systems Pty Ltd. (Australia)

xv Nanostructures for high-efficiency photovoltaics (Plenary Paper) [7047-102]

H. A. Atwater, California Institute of Technology. (United States)

xix Reliability of $P \vee$ systems (Plenary Paper) [7048-101]

J. H. Wohlgemuth, BP Solar International Inc. (United States)

CHARGE INJECTION AND TRANSPORT IN ORGANIC LIGHT EMITTING DIODES AND SOLAR CELLS: JOINT SESSION WITH CONFERENCE 7051

705204 A doping mechanism for organic semiconductors derived from SXPS measurements on co-evaporated films of CuPc and TCNQ and on a TCNQ/CuPc interface [7052-03]

T. Mayer, C. Hein, J. Härter, E. Mankel, W. Jaegermann, Darmstadt Univ. of Technology (Germany)

RELIABILITY OF FLEXIBLE PACKAGING: JOINT SESSION WITH CONFERENCE 7048

705205 Efficiency and stability investigations of large area organic photovoltaic modules (Invited Paper) [7052-04]

D. W. Laird, S. Jia, J. Bernkopf, J. Krieg, J. Benson-Smith, S. Li, S. P. Williams, Plextronics, Inc. (United States)

ACCURATE MEASUREMENT OF THE EFFICIENCY OF ORGANIC PHOTOVOLTAIC DEVICES

7052 OD Accurate measurement of organic solar cell efficiency (Invited Paper) [7052-12]

K. Emery, T. Moriarty, National Renewable Energy Lab. (United States)

7052 OE Measurement issues of organic solar cell (Invited Paper) [7052-13]

G. Li, V. Shrotriya, Solarmer Energy Inc. (United States); J. Huang, Y. Yang, UCLA (United States)

7052 OF Performance measurement of dye-sensitized solar cells and organic polymer solar cells (Invited Paper) [7052-14]

Y. Hishikawa, National Institute of Advanced Industrial Science and Technology (Japan) 
MULTILAYER ORGANIC PHOTOVOLTAICS WITH A P-I-N STRUCTURE

$7052 \mathrm{OH}$ Efficient organic $p$-i-n solar cells having very thick codeposited $i$-layer composed of highly purified organic semiconductors (Invited Paper) [7052-15]

M. Hiramoto, Institute for Molecular Science (Japan); K. Sakai, Osaka Univ. (Japan)

$70520 \mathrm{~J}$ Organic photovoltaic cell based on benzoporphyrin with p-i-n junction [7052-17]

Y. Sato, T. Niinomi, Y. Abe, Y. Matsuo, Japan Science and Technology Agency (Japan);

E. Nakamura, Japan Science and Technology Agency (Japan) and The Univ. of Tokyo

(Japan)

PHYSICS OF MULTI- AND BULK HETEROJUNCTION SOLAR CELLS

7052 ON Implications of a reduced polaron recombination on polymer: fullerene solar cells [7052-21]

C. Deibel, A. Wagenpfahl, A. Baumann, Julius-Maximilians-Univ. of Würzburg (Germany);

V. Dyakonov, Julius-Maximilians-Univ. of Würzburg (Germany) and Bavarian Ctr. for Applied

Energy Research (Germany)

705200 Interdigitated photoconductors using organic and small molecule materials [7052-22]

A. C. Niemeyer, Los Alamos National Lab. (United States) and Univ. of Florida (United

States); I. H. Campbell, Los Alamos National Lab. (United States); F. So, Univ. of Florida

(United States); B. K. Crone, Los Alamos National Lab. (United States)

HYBRID SOLAR CELLS WITH ORGANIC AND INORGANIC COMPONENTS

7052 OS Improved performance of polymer/ $/ \mathrm{TiO}_{2}$ nanorods bulk heterojunction photovoltaic devices by interface modification [7052-26]

Y.-Y. Lin, S. S. Lee, T.-H. Chu, W.-F. Su, C.-W. Chen, National Taiwan Univ. (Taiwan)

NEW MATERIALS FOR ORGANIC PHOTOVOLTAICS

7052 OW Development of Si-bridged conjugated donor polymers for high-efficiency bulkheterojunction photovoltaic devices (Invited Paper) [7052-31]

E. Wang, L. Wang, L. Lan, J. Chen, J. Peng, Y. Cao, South China Univ. of Technology (China)

7052 OY A low-energy gap and fully regioregular poly(3-Dodecyl-2,5-thienylenevinylene) for photovoltaics [7052-33]

C. Zhang, T. Matos, S. Maaref, E. Annih, S.-S. Sun, Norfolk State Univ. (United States);

J. Zhang, X. Jiang, Univ. of South Florida (United States)

POSTER SESSION

705212 Schottky barrier formation using composite of polyaniline containing iron oxides [7052-37]

H. A. Motaweh, Alexandria Univ. (Egypt); T. G. Abdel-Malik, Univ. of Minia (Egypt) 
705213 Dye-sensitized solar cells based on ZnO nanorod arrays [7052-38]

Y. Xie, South Dakota State Univ. (United States); S. Li, T. Zhang, Beijing Jiaotong Univ.

(China); P. Joshi, South Dakota State Univ. (United States); H. Fong, South Dakota School of Mines and Technology (United States); M. Ropp, D. Galipeau, Q. Qiao, South Dakota State Univ. (United States)

705214 Calamatic liquid crystal blends for organic photovoltaics [7052-39]

C. Lei, M. S. Al Khalifah, M. O'Neill, M. P. Aldred, S. P. Kitney, P. Vlachos, S. M. Kelly, Univ. of Hull (United Kingdom)

705215 Fabrication of bulk heterojunction photovoltaic cells with controlled distribution of $p-n$ components by evaporative spray deposition using ultradilute solution [7052-40]

M. Shakutsui, T. Iwamoto, R. Maeda, T. Tsutsui, K. Fujita, Kyushu Univ. (Japan)

705216 Efficacious photocurrent generation and carrier transport by quantum dot decorated carbon nanotubes [7052-41]

C. Biswas, S. Y. Jeong, S. C. Lim, D. J. Bae, Y. H. Lee, Sungkyunkwan Univ. (Korea, Republic of); H. J. Shin, S.-M. Yoon, J. Y. Choi, Samsung Advanced Institute of Technology (Korea, Republic of); O. H. Cha, M. S. Jeong, Advanced Photonics Research Institute, GIST (Korea, Republic of); D. Perello, M. Yun, Univ. of Pittsburgh (United States)

705217 Fabrication and characterisation of polymer based solar cells [7052-42]

L. H. Slooff, S. Böhme, W. Eerenstein, S. C. Veenstra, W. Verhees, J. M. Kroon, ECN-Solar Energy (Netherlands); T. Söderström, Univ. of Neuchâtel (Switzerland)

705219 Charge transport properties of low temperature solution processable poly(3hexylthiophene)/surface modified $\mathrm{TiO}_{2}$ bulk heterojunction systems [7052-45] F.-C. Hsu, Y.-C. Huang, Y.-C. Liao, J.-H. Hsu, W.-C. Yen, C.-W. Chen, W.-F. Su, National Taiwan Univ. (Taiwan)

7052 1B Improving the conductivity of hole injection layer by heating PEDOT:PSS [7052-47] K.-H. Tsai, S.-C. Shiu, C.-F. Lin, National Taiwan Univ. (Taiwan)

$70521 G \quad$ New deep-red-emitting polymers derived from indenoindene and benzothiadiazole for photovoltaic cells [7052-53]

H. Suh, Y. Jin, J. Moon, S. Song, Pusan National Univ. (Korea, Republic of); S. H. Kim, K. Lee, Gwangju Institute of Science and Technology (Korea, Republic of)

$7052 \mathrm{1H} \quad$ Colloidal crystals as nanostructured templates for organic solar cells [7052-54]

S. Berhanu, M. A. McLachlan, D. W. McComb, Imperial College London (United Kingdom); T. S. Jones, Univ. of Warwick (United Kingdom)

$70521 \mathrm{~J} \quad$ Organic photovoltaic cells based on functionalized pentacenes [7052-56] P. A. Lane, L. C. Palilis, G. P. Kushto, Z. H. Kafafi, Naval Research Lab. (United States);

B. Purushothaman, J. E. Anthony, Univ. of Kentucky (United States) 
Downloaded From: https://www.spiedigitallibrary.org/conference-proceedings-of-spie on 26 Apr 2023

Terms of Use: https://www.spiedigitallibrary.org/terms-of-use 


\title{
Conference Committee
}

\author{
Symposium Chair
}

Zakya H. Kafafi, National Science Foundation (United States)

Conference Chair

Zakya H. Kafafi, National Science Foundation (United States)

Conference Cochairs

Christoph J. Brabec, Konarka Austria (Austria)

Paul A. Lane, Naval Research Laboratory (United States)

Program Committee

Katsuhiko Fujita, Kyushu University (Japan)

Rene A. J. Janssen, Technische Universiteit Eindhoven (Netherlands)

Bernard Kippelen, Georgia Institute of Technology (United States)

Kwanghee Lee, Gwangju Institute of Science and Technology (Korea, Republic of)

Toby B. Meyer, Solaronix SA (Switzerland)

Peter Peumans, Stanford University (United States)

Sean E. Shaheen, University of Denver (United States)

Yasuhiko Shirota, Fukui University of Technology (Japan)

Session Chairs

$1 \quad$ Charge Injection and Transport in Organic Light Emitting Diodes and Solar Cells: Joint Session with Conference 7051

Christoph J. Brabec, Konarka Austria (Austria)

2 Reliability of Flexible Packaging: Joint Session with Conference 7048

John Pern, National Renewable Energy Laboratory (United States)

3 Novel Structures and Materials for Organic Photovoltaics

Garry Rumbles, National Renewable Energy Laboratory (United States)

4 Reliability of Organic Photovoltaics: Joint Session with Conference 7048

Linda Sapochak, Pacific Northwest National Laboratory (United States) 
5 Accurate Measurement of the Efficiency of Organic Photovoltaic Devices

Yang Yang, University of California, Los Angeles (United States)

6 Multilayer Organic Photovoltaics with a p-i-n Structure

Toby B. Meyer, Solaronix SA (Switzerland)

$7 \quad$ Physics of Multi- and Bulk Heterojunction Solar Cells

Rene A. J. Janssen, Technische Universiteit Eindhoven (Netherlands)

$8 \quad$ Hybrid Solar Cells with Organic and Inorganic Components

Toby B. Meyer, Solaronix SA (Switzerland)

9 New Materials for Organic Photovoltaics

Paul A. Lane, Naval Research Laboratory (United States) 